УДК 37.091.312-024.87:004.77

DOI: 10.37026/2520-6427-2021-106-2-64-70
Ніна ТИМЧИНА,

старший викладач кафедри природничо-математичної освіти Рівненського обласного інституту післядипломної педагогічної освіти, м. Рівне, Україна

ORCID: 0000-0001-9247-1851

e-mail:n.tymchyna@roippo.org.ua

Віталія ТИМЧИНА,

старший викладач кафедри природничо-математичної освіти Рівненського обласного інституту післядипломної педагогічної освіти, м. Рівне, Украӥна

ORCID: 0000-0002-1030-6463

e-mail:v.tymchyna@roippo.org.ua

Наталія КРУТОВА,

кандидат педагогічних наук, доиент кафедри природничо-математичної освіти Рівненського обласного інституту післядипломної педагогічної освіти, м. Рівне, Украӥна

ORCID: 0000-0002-2033-2497

e-mail:n.krutova@roippo.org.ua

\title{
КОЛЕКТИВНА РОБОТА УЧНІВ ЗАКЛАДІВ ЗАГАЛЬНОЇ СЕРЕДНЬОЇ ОСВІТИ ІЗ ЗАСТОСУВАННЯМ ВІРТУАЛЬНОЇ ДОШКИ В УМОВАХ ДИСТАНЦЙНОГО НАВЧАННЯ
}

\begin{abstract}
Анотація. У статті окреслено питання використання сучасних циифрових інструментів для колективної роботи в умовах дистаниійного навчання. Розглянуто засадничі положення досліджуваної проблеми у поглядах вітчизняних та закордонних науковців на основі аналізу психолого-педагогічної та методичної літератури щьодо здійснення спільної роботи в освітньому прочесі засобами онлайн-інструментів. 3'ясовано сутність понять «колективна робота», "дистаниійне навчання».

Зроблено акиент на доиільності використання онлайн-дошки як інструменту для здійснення дистаниіииного навчання та модернізації освітнього процесу. Проаналізовано можливості віртуальної дошки Bitpaper. Наведено алгоритм створення дошки та визначено умови роботи за різними тарифними планами. Ознайомлено з інструментарієм онлайн-середовища та здійснено аналіз функціонального призначення окремих
\end{abstract}

інструментів, можливості налаштувань дизайну «полотна», «аркуша» дошки.

Визначено переваги Bitpaper, зокрема: підтримка кирилиці; великий вибір фігур та форм для створення малюнків; можливість прачювати на таджетах різних типів; писати, друкувати текстові повідомлення, працювати з формулами, зберігати створені дошки як зображення або pdf-документи.

Наведено приклади дидактичних вправ для спільної роботи школярів в умовах дистаниійного навчання. Узагальнено результати дослідження і оцінено ефективність їх використання в освітньому проиесі. Визначено перспективи дослідження щзодо використання віртуальних дошок різних типів для вивчення навчальних предметів в умовах циифровізації освіти.

Ключові слова: колективна робота, дистаниійне навчання, онлайн-інструменти, віртуальна дошка, учні, освітній процес.

\author{
Nina TYMCHYNA, \\ Senior lecturer of Department \\ of Natural and Mathematical education, \\ Rivne Regional Institute \\ of Postgraduate Pedagogical Education, \\ Rivne, Ukraine \\ ORCID: 0000-0001-9247-1851 \\ e-mail: n.tymchyna@roippo.org.ua
}




\author{
Vitaliia TYMCHYNA, \\ Senior lecturer of Department \\ of Natural and Mathematical Education, \\ Rivne Regional Institute \\ of Postgraduate Pedagogical Education, \\ Rivne, Ukraine \\ ORCID: 0000-0002-1030-6463 \\ e-mail:v.tymchyna@roippo.org.ua \\ Nataliia KRUTOVA, \\ Candidate of pedagogical sciences, \\ Associate Professor \\ of Natural and Mathematical education, \\ Rivne Regional Institute \\ of Postgraduate Pedagogical Education, \\ Rivne, Ukraine \\ ORCID: 0000-0002-2033-2497 \\ e-mail:n.krutova@roippo.org.ua
}

\title{
IMPLEMENTATION OF COLLECTIVE WORK OF STUDENTS IN THE CONDITIONS OF DISTANCE LEARNING WITH USE OF MODERN ONLINE TOOLS
}

\begin{abstract}
The article outlines the use of modern tools for teamwork in distance learning. The basic provisions of the researched problem in the views of native and foreign scientists based on the analysis of psychological-pedagogical and methodical literature in the issue of collective work in the educational process with means of online tools are considered. The essence of the concepts such as "teamwork» and "distance learning» is clarified. However, regardless of the form of education, to increase the effectiveness of educational activities of students collective interaction is important because it increases the interest and determines the success of subjects.

Online classes are the new reality. Emphasis is placed on the feasibility of using the online board as a tool of distance learning and modernization of the educational process. The possibilities of such tools are analyzed and the virtual board Bitpaper is extracted. The algorithm of creation of a board is resulted and working conditions in various tariff plans are defined. In this article we are familiarized with the tools of the online environment and the functional purpose of individual tools and the ability to adjust the design of the «canvas» or "sheet» of the board are analyzed.

The advantages of Bitpaper are defined and they are evident. Cyrillic is supported. There is a wide choice of figures and forms for creation of drawings. Students can work on different types of gadgets. They write and print text messages, work with formulas or save the created boards as images or pdf-documents. The online teacher should use the board to explain new material and to visualize some information in the educational process. This board can be used to create and perform interactive tasks, for work with textual information or making a collective drawing, reflection, art minutes, etc. Some examples of didactic exercises for collective work of schoolchildren in the conditions of distance learning are given here as well.

The results of the research are generalized and the efficiency of its use in the educational process is estimated.
\end{abstract}

The prospects of research of using virtual boards of different types for studying subjects in the conditions of digital education are defined.

Key words: teamwork, distance learning, online tools, virtual board, students, educational process.

Постановка проблеми. Зважаючи на сучасні вимоги суспільства, пов'язані із пандемією, та стрімкий розвиток комп'ютерних технологій, все більшої актуальності набуває змішане та дистанційне навчання. Проте незалежно від форми навчання важливою складовою підвищення ефективності освітньої діяльності школярів є колективна взаємодія, яка підсилює інтерес та обумовлює успіхи з навчальних предметів.

Крім того, аналіз вимог сучасних роботодавців свідчить, що у перспективі до 2030 року найбільший попит матимуть уміння працювати в команді, вирішувати комплексні проблеми, аналітично мислити, виявляти ініціативність, управляти проєктами та змінами (Зінченко, Саприкіна, 2016).

Із метою формування означених умінь і навичок створена достатня кількість доцільних цифрових інструментів. Однак на сучасному етапі колективні види роботи, можливості інструментів для спільної взаємодіï, платформи для об'єднання їх у структурні моделі, що мають вплив на успішність учнів та сприяють упровадженню в змішане навчання принципу взаємодії «вчитель - учень» і «учень - учень», ще недостатньо досліджені, що й стало стимулом до написання цієї публікації.

Аналіз наукових досліджень і публікацій. Аналіз науково-педагогічної літератури з проблеми використання колективної роботи в освітньому процесі доводить їі неоднозначність. Зокрема, I. Бех зазначає, що лише в дитячій колективній діяльності проявляються надзвичайно сильні у виховному відношенні впливи, і саме такі, які неможливі в інших видах 
міжособистісних взаємин («дорослий - дитина» чи «батьки - дитина») (2006).

В. Дяченко, аналізуючи колективну працю, зазначає, що в цьому контексті «всі працюють зі всіма і всі вчаться у всіх, тобто реалізується закон життя здорового колективу - загальна співпраця і взаємодія товаришів» (2004).

Сучасні вчені колективну діяльність тлумачать як спільну, добровільно прийняту особистістю сумісну діяльність достатньо високого рівня колективності, спрямовану на досягнення суспільно значимих цілей та, з позиції мотивації, орієнтовану і на свій процес, i на свій результат (СтудопедіЯ: вебсайт).

Колективна навчально-пізнавальна діяльність учнів $є$ одним із найважливіших факторів не лише у формуванні особистості школяра, а й у забезпеченні продуктивного характеру процесу пізнання загалом. Дослідження 3 цієї проблеми здійснювали відомі вітчизняні та зарубіжні психологи (А. Петровський, Л. Занков, Д. Ельконін, А. Леонтьєв, Л. Бабанін, I. Богданов, I. Васильєва, С. Маталига, Е. Осипова, М. Петрова) та педагоги (Х. Лійметс, А. Мудрик, В. Дяченко, І. Страхов, В. Оконь, Н. Длугунович, Л. Іванова, О. Скорнякова, М. Бургін, К. Горбунова, А. Літвінчук, Л. Пироженко, Н. Побірченко та інші).

Важливу увагу у публікації приділено дослідженню різних видів цифрових інструментів та їх використанню для спільної роботи в освітньому процесі. Так, застосування мультимедійних, комп'ютерних технологій досліджували Р. Гайдамаха, А. Голобородько, О. Данилова, Т. Кристопчук, В. Люльчик, О. Манако та ін. Використання освітніх вебтехнологій аналізували Т. Винарчук (2018), А. Вітковська-Пелань, I. Захарова, М. Кадемія, М. Козяр (2015), Н. Коломійчук, О. Кучай, Т. Пуніна, Г. Стеценко, І. Худякова, Л. Амхаг (2019), В. Тимчина, Н. Тимчина (2019) та ін. Водночас проблема впровадження колективних форм роботи в освітньому процесі та їх реалізації у дистанційному навчанні сучасними цифровими інструментами залишається досить актуальною, однак недостатньо вивченою.
У зв'язку з цим метою нашого дослідження $є$ перевірка ефективності та доцільності використання онлайн-інструментів для колективної роботи учнів закладів загальної середньої освіти із застосуванням віртуальної дошки в умовах дистанційного навчання.

Виклад основного матеріалу дослідження. Дистанційне навчання - це тип навчання, що базується на освітній взаємодії віддалених один від одного викладачів і здобувачів освіти та реалізується за допомогою телекомунікаційних технологій і ресурсів мережі «Інтернет». Для його організації необхідна віртуальна інтерактивна дошка - соціальний сервіс, що працює як дошка для організації колективної роботи в умовах дистанційного навчання. Онлайн-дошка виглядає як робочий простір, «кольорове полотно», «білий аркуш», на якому можна виконувати певні дії. Одночасно 3 організатором у режимі реального часу цей робочий простір і всі зміни на ньому є наочними та доступними всім учасникам освітнього процесу, яким надано доступ та запрошено до спільної взаємодії. Візуально дошка виглядає як програма для малювання онлайн, створення та редагування спільних онлайн-документів, але 3 додатковими функціями, які допоможуть організувати роботу із класом та зробити ії більш інтерактивною у режимі дистанційного навчання.

Сервісів, які забезпечують можливість роботи 3 онлайн-дошкою, є досить багато, зокрема Jamboard, BitPaper, Draw Chat, Scrumblr, IDroo, O-Whiteboard, AWW board, Twiddla, Miro та інші.

Розглянемо детальніше можливості та переваги віртуальної дошки Bitpaper. Отже, BitPaper.io - це онлайн-сервіс для спільної роботи, який за відгуками освітян визнаний одним із кращих. Щоб розпочати роботу з цією дошкою, потрібно перейти на сайт за покликанням https://www.bitpaper.io/ та зареєструватися. Реєстрацію можна здійснити через облікові записи google чи facebook або за електронною адресою. Після цього у правому верхньому куті вікна програми достатньо натиснути кнопку Create Paper, ввести назву дошки та почати роботу із сервісом (див. рис. 1).

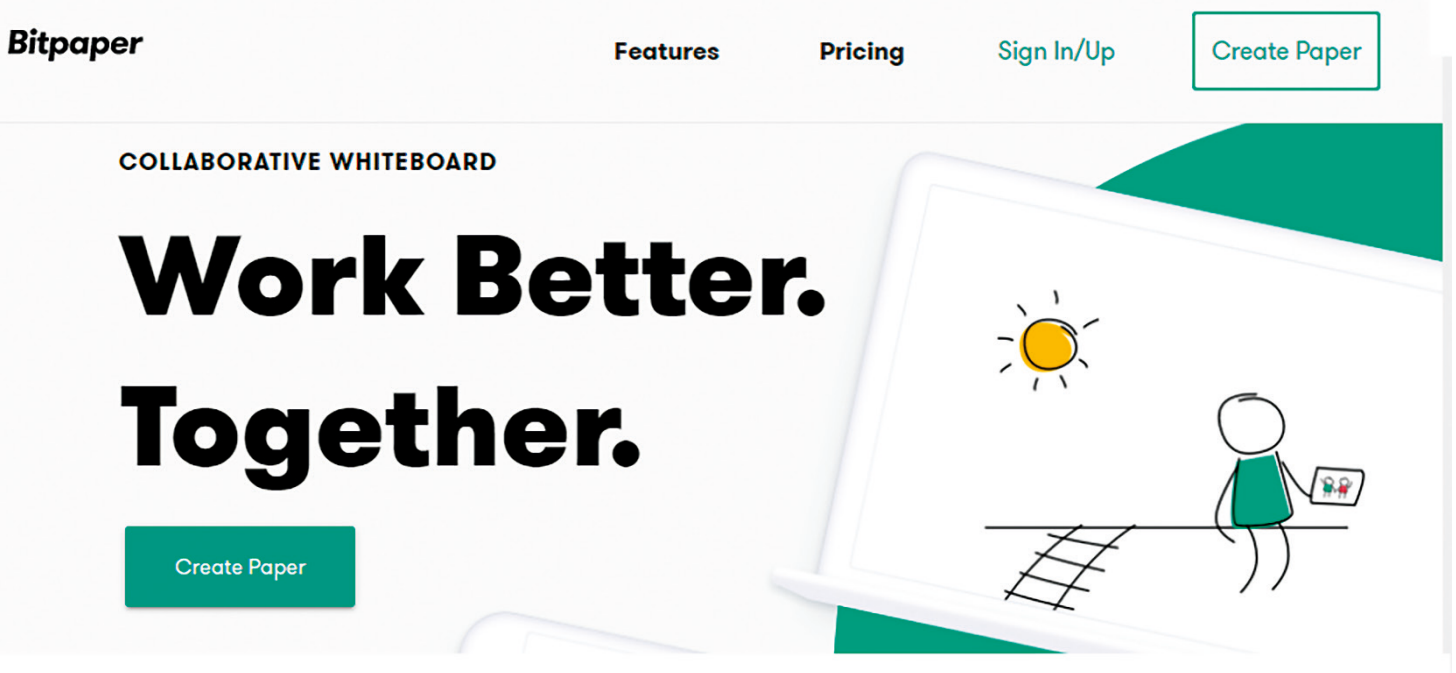

Pис.1. Вікно сайту https://www.bitpaper.io/ 
Учням реєструватися не потрібно, адже вони приєднуються до дошки за покликанням, котре надсилає вчитель. Після реєстрації зазвичай відкривається відео, в якому перераховані функції, що будуть доступні під час використання означеного сервісу.

Працювати $з$ цією дошкою можна безоплатно або за різними тарифними планами, про що можна дізнатися у розділі Pricing. Безкоштовний пакет Free дозволяє: приєднуватися до дзвінків; створювати файли, зберігати документи. У цьому режимі можна створювати одну дошку на місяць, зберігати полотна у форматі pdf та використовувати для візуалізації як інфографіку. Проте за потреби на цій дошці можна створювати до 40 нових полотен, а збережені полотна видалити, щоб не заважали в роботі. Відповідно за тарифом ви зможете створювати 20 або 60 дошок на місяць і здійснювати ті ж самі функції, що і в безкоштовній версії.

Інтерфейс дошки Bitpaper.io досить простий та зрозумілий, адже в ньому достатньо функціоналу для виконання різних завдань (див. рис. 2).

Працюючи 3 дошкою, можна виконувати такі функції:
- писати рукописні тексти мишкою, пальцем або стилусом, залежно від пристрою, вибравши інструменти «Ручка» або «Маркер»;

- вставляти власні зображення, виконуючи певні завдання та доповнюючи їх наочністю;

- створювати власні та колективні малюнки, схеми за допомогою інструменту «Форми» (достатньо великий вибір);

- коментувати, друкувати текстові повідомлення;

- працювати з формулами;

- запрошувати багатьох учнів, надавши покликання на дошку або скопіювавши його в адресному рядку;

- працювати на гаджетах різних типів;

- телефонувати та спілкуватись у чаті (на платному тарифному плані);

- зберігати створені дошки як зображення або pdf-документи (див. рис. 3).

Важливо звернути увагу на можливості вертикальної панелі інструментів. Досить перспективним $\epsilon$ інструмент «Фони та сітки», що дозволяє налаштувати фон конкретного полотна у лінійку чи клітинку, причому за потреби можна вибрати колір фону та ліній,

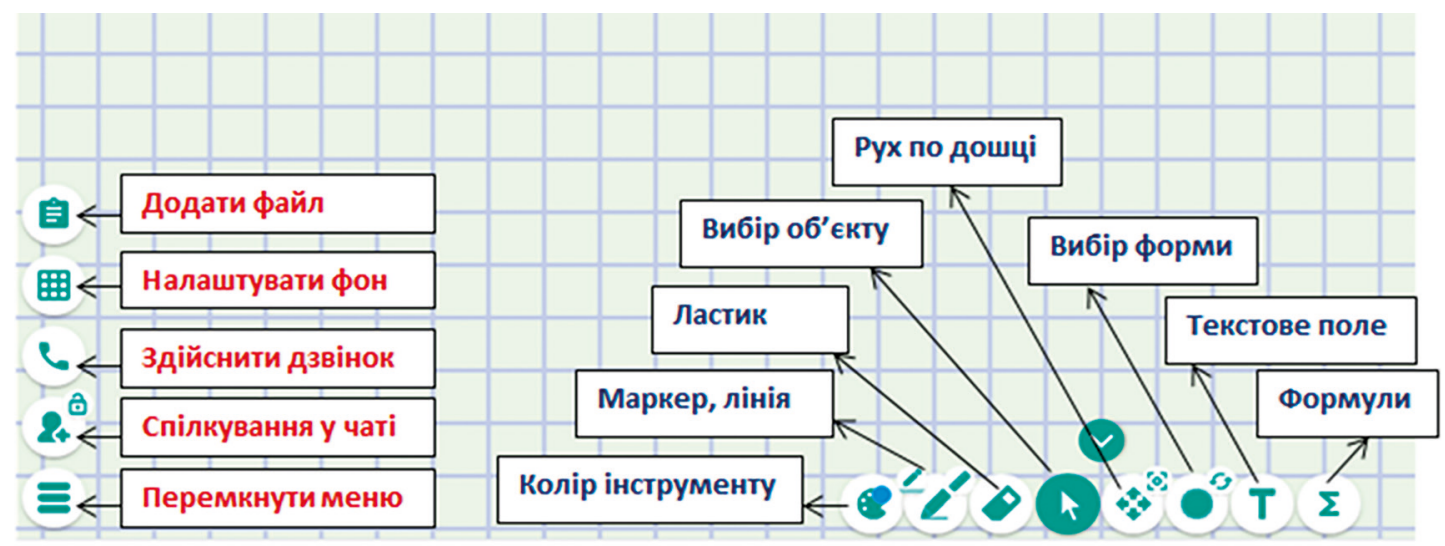

Рис. 2. Функиіонал дошки Bitpaper.io

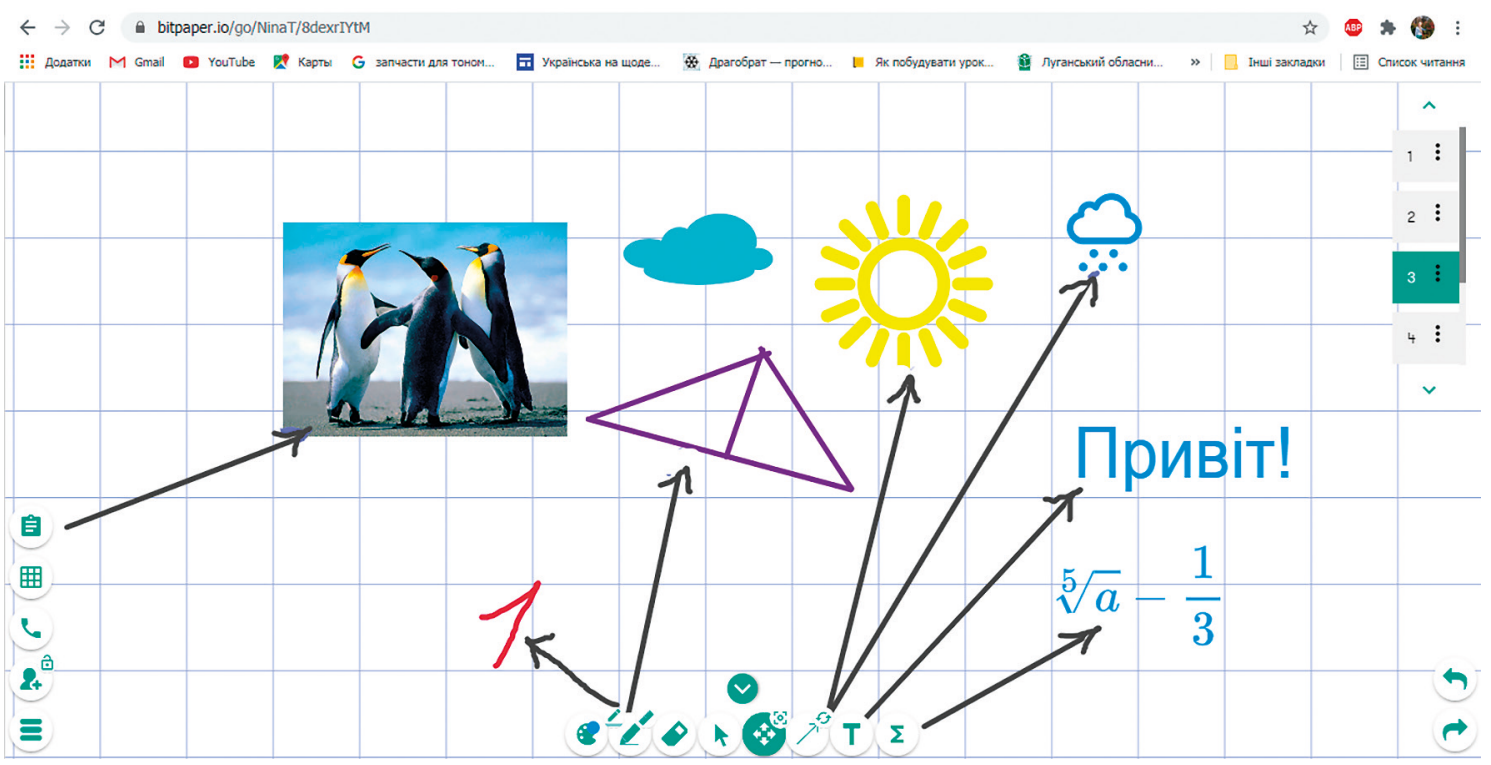

Рис. 3. Робота з інструментарісм онлайн-дошки 
маючи широкий спектр відтінків, підібрати товщину ліній, встановити висоту та ширину клітинки (див. рис. 4).

Наприклад, учитель початкових класів, проводячи онлайн-урок під час дистанційного навчання, може вибрати дошку з великими клітинками та продемонструвати як правильно та каліграфічно писати літери чи цифри, звернути увагу дітей на помилки, допущені під час спільної роботи.

Онлайн-дошку можна використовувати для пояснення нового матеріалу, візуалізації інформації в освітньому процесі, створення та виконання інтерактивних завдань, спільної роботи $з$ текстовою інформацією, 3 метою рефлексії, проведення артхвилинок тощо. Актуальним $є$ застосування дошки під час дистанційного навчання на уроках образотворчого мистецтва та технологій із метою створення колективних малюнків, схем та макетів, оскільки Bitpaper має в своєму арсеналі хороший функціонал та досить потужний набір фігур та форм (див. рис.5).

Підсумовуючи зазначене вище, варто відзначити, що онлайн-дошка Bitpaper $€$ сучасним, доступним, простим та актуальним інструментом для спільної роботи, особливо в умовах дистанційного та змішаного навчання. Цей соціальний сервір має таке наповнення: сітка в клітинку, розмір якої можна налаштувати або прибрати; інструмент для малювання довільних ліній, прямих; великий набір геометричних фігур. Завдяки цьому забезпечується можливість друкувати текст, вставляти зображення або документи, експортувати зображення iз дошки у pdf. Дошкою можна ділитися з будь-якою

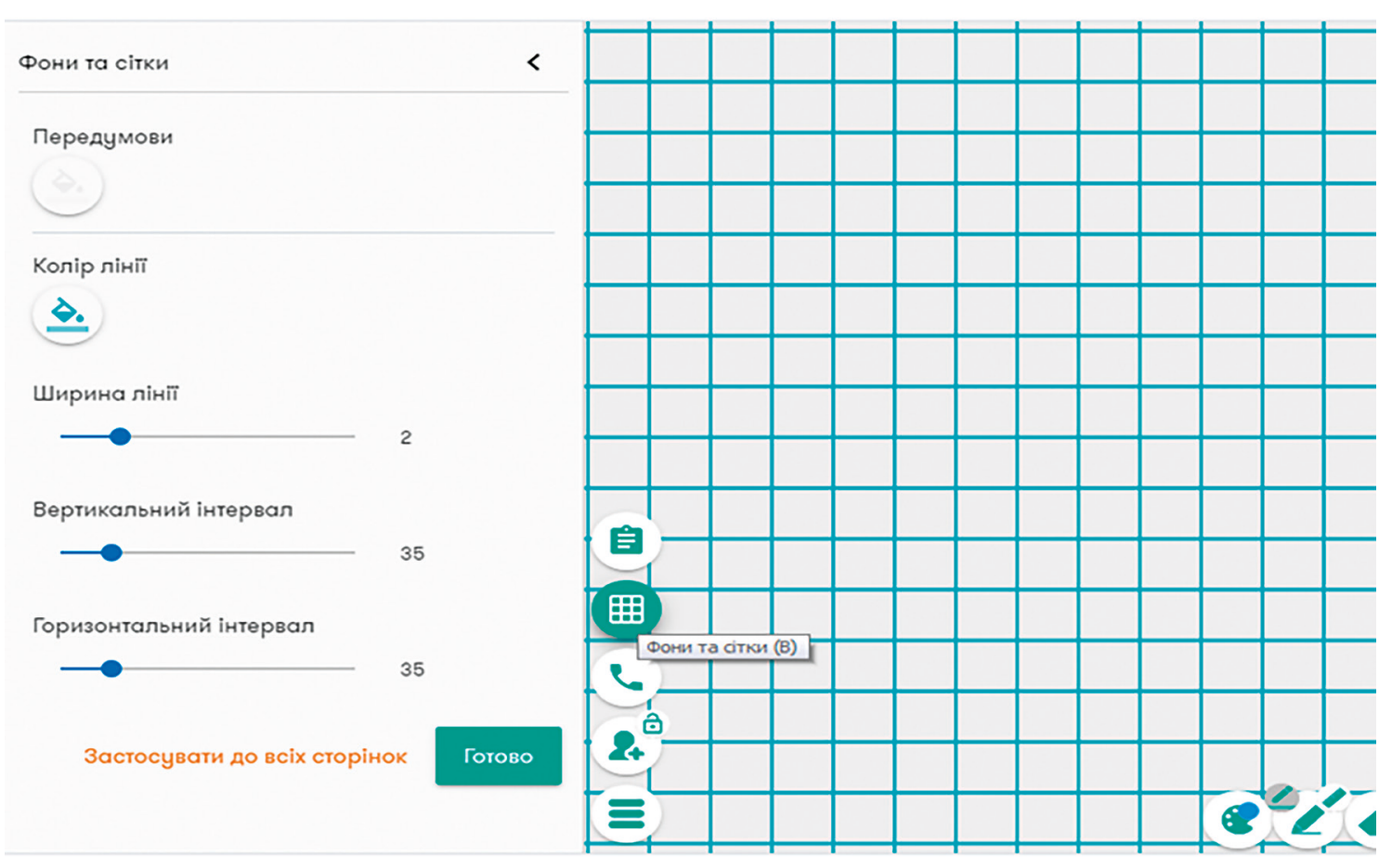

Рис. 4. Налаштування фону та сітки дошки Bitpaper

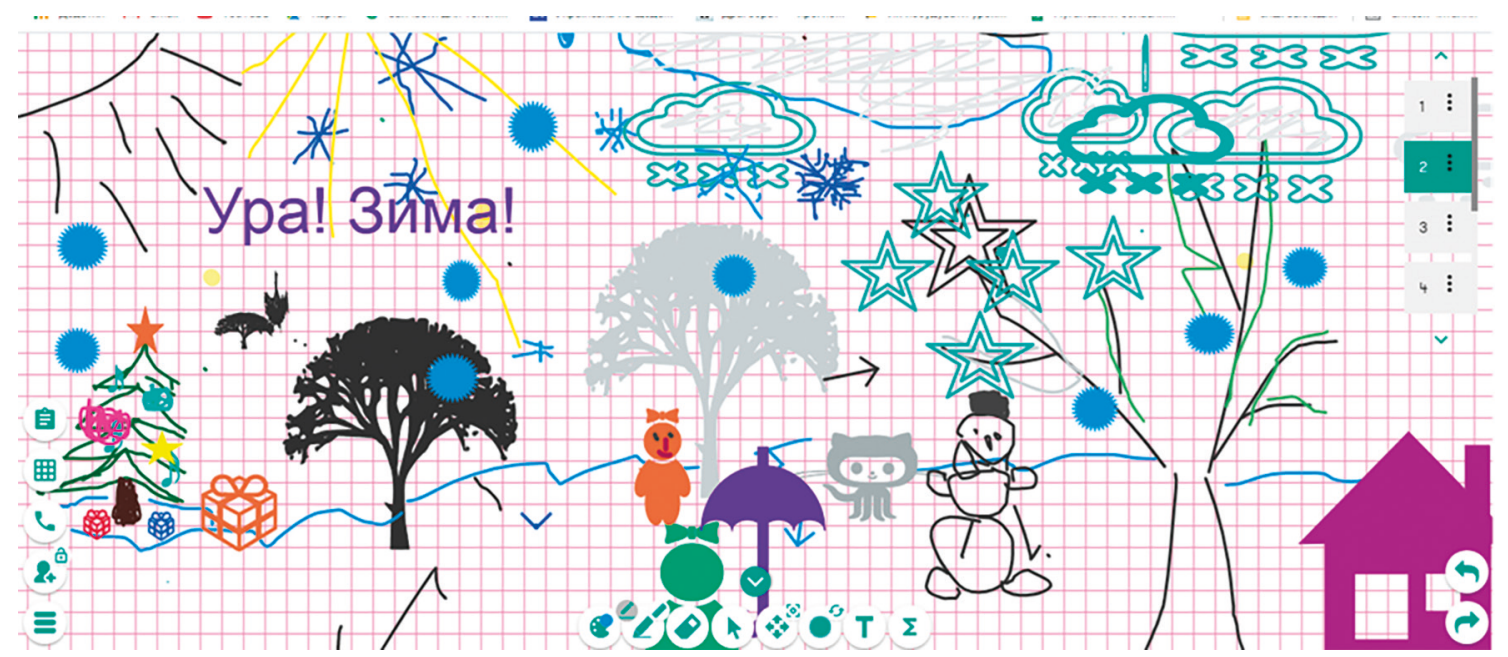

Рис. 5. Приклад колективного дитячого малюнку з теми «Зима прийшла» 
кількістю учнів за допомогою покликання. На ній можна писати, малювати та виконувати інші дії одночасно зі всіма учасниками на гаджетах різних типів. Все, що було напрацьовано під час уроку, зберігається на дошці, тому учні мають змогу використовувати іiі для складання конспекту і після закінчення заняття. Базова версія дозволяє створювати одну дошку на місяць, але на кожній дошці може бути до 40 окремих сторінок. Кожна сторінка - умовно нескінченний простір для малювання, по якому можна переміщуватися.

Отже, досліджуваний у статті онлайн-інструмент для колективної роботи є досить ефективним, однак на практиці його використовує досить мала кількість освітян. Із метою визначення цифрових середовиш для дистанційного навчання та інструментів для спільної взаємодії, що використовують учителі в освітньому процесі, ми провели дослідження у жовтнілистопаді 2020 року. В опитуванні взяли участь 168 педагогів різного фаху та слухачі курсів підвищення кваліфікації Рівненського обласного інституту післядипломної педагогічної освіти. Результати експерименту виявилися невтішними: лише $11 \%$ респондентів використовують онлайн-дошки у професійній діяльності, іноді застосовують - 13\%, не використовують взагалі - $76 \%$ опитаних (із них $24 \%$ учителів взагалі не були ознайомлені з таким соціальним сервісом). Із дошок, що використовують учителі, найбільш затребуваною $є$ Jamboard, a Bitpaper виявилась новинкою, проте цікавою та багатофункціональною.

Висновки. Проаналізувавши результати нашого дослідження, ми дійшли висновку, що у ході оновлення освітніх програм підвищення кваліфікації важливо звертати увагу на означену тематику, оскільки переважна більшість освітніх закладів області працює в умовах дистанційного навчання. Крім того, до багатьох програм підвищення кваліфікації на 2021 рік розроблені теми щодо доцільності використання відповідних онлайн-інструментів, зокрема інтерактивних дошок.

Сучасні цифрові ресурси надають практично необмежені можливості для самостійної та спільної творчої діяльності педагогів і учнів, а також є інструментом, за допомогою якого вчителі можуть якісно оновлювати організацію освітнього процесу, змінювати методи й організаційні форми своєї роботи, підвищувати власний кваліфікаційний рівень (Крутова, 2019).

Перспективи подальших досліджень убачаємо в продовженні дослідження означеної проблематики, порівнянні можливостей онлайн-дошок, що є доцільним та дієвим засобом реалізації освітнього процесу в умовах дистанційного навчання.

\section{СПИСОК ВИКОРИСТАНОЇ ЛІТЕРАТУРИ}

Зінченко, А. Г., Саприкіна, М. А. (2016). Навички для України 2030: погляд бізнесу. Київ: ТОВ «Видавництво «Юстон». 36 с.

Бех, І. Д. (2006). Виховання особистості: Сходження до духовності. Київ: Либідь. 255 с.

Дьяченко, В. (2004). Коллективный способ в обучении: дидактика в диалогах. Москва: Народное образование. 352 с.

Колективна діяльність як спосіб навчально-пізнавальної та виховної взаємодії учнів у різновікових групах. Форми іï̈ організації. СтудопедіЯ: вебсайт. URL: https://studopedia.com.ua/1_58980_kolektivna-diyalnistyak-sposib-navchalno-piznavalnoi-ta-vihovnoi-vzaiemodiiuchniv-u-riznovikovih-grupah-formi-ii-organizatsii.html (дата звернення: 18.04.2021).

Винарчук, Т. М. (2018). Роль і значення освітніх вебресурсів у забезпеченні безперервної освіти педагога. URL: https://www.narodnaosvita.kiev.ua/Narodna osvita/vupysku/10/statti/vinarchyk_t.hm (дата звернення: 11.04.2021).

Козяр, М. М. (2015). Нові технології навчання виклик сучасності. Сучасні інформаційні технологї̈ та інноваційні методики навчання в підготовиі фахівиів: методологія, теорія, досвід, проблеми: збірник наукових праць. Вінниця. № 41. С. 3-7.

Amhag, L., Hellström, L., Stigmar, M. (2019). Teacher educators' use of digital tools and needs for digital competence in higher education. Journal of Digital Learning in Teacher Education. 35 (4). Pp. 203-220.

Тимчина, Н. С., Тимчина, В. І., Позднякова, Т. Є. (2019). Сайт як складова інформаційного середовища закладу освіти. Нова педагогічна думка: науково-методичний журнал. Рівне: РОІППО. № 2 (98). С. 61-65.

Крутова, Н. І. (2019). Інтеграція інформаційно-комунікаційних технологій у систему підвищення кваліфікації педагогічних працівників. Нова педагогічна думка: науково-методичний журнал. Рівне: РОІППО. № 1 (97). С. 34-36.

Martin, A. (2020). How to optimize online learning in the age coronavirus (COVID-19): a 5-point for guide for educators. UNSW Newsroom. Vol. 53. № 9. Pp. 1-30.

\section{REFERENCES}

Bekh, I. D. (2006). Vykhovannya osobystosti: Skhodzhennya do dukhovnosti [Education of personality: Ascent to spirituality]. Kyyiv: Lybid. 255 s. [in Ukrainian].

Zinchenko, A. H., Saprykina, M. A. (2016). Navychky dlya Ukrayiny 2030: pohlyad biznesu [Skills for Ukraine 2030: a view of business]. Kyyiv: TOV «Vydavnytstvo «Yuston». 36 s. [in Ukrainian].

D'jachenko, V. (2004). Kollektivnyj sposob obuchenii: didaktika $\mathrm{v}$ dialogah [Collective way of learning: didactics in dialogues]. Moskva: Narodnoe obrazovanie. 352 s. [in Russian].

Kolektyvna diyal nist yak sposib navchalno-piznavalnoyi ta vykhovnoyi vzayemodiyi uchniv u riznovikovykh hrupakh. Formy yiyi orhanizatsiyi [Collective activity as a way of educational and cognitive and educational interaction of students in different age groups]. Studopediya: vebsait. URL: https://studopedia.com. ua/1_58980 kolektivna-diyalnist-yak-sposib-navchalno-piznavalnoi-ta-vihovnoi-vzaiemodii-uchniv-u-riznovikovih-grupah-formi-ii-organizatsii.html (data zvernennya: 18.04.2021). [in Ukrainian].

Vynarchuk, T. M. (2018). Rol i znachennya osvitnikh vebresursiv u zabezpechenni bezperervnoyi osvity pedahoha [The role and importance of educational Web resources in providing continuing education for teachers]. URL: https://www.narodnaosvita.kiev.ua/Narodna osvita/vupysku/10/statti/vinarchyk t.hm (data zvernennya: 11.04.2021). [in Ukrainian].

Kozyar, M. M. (2015). Novi tekhnolohiyi navchannya - vyklyk suchasnosti [New learning technologies as a 
challenge of nowdays]. Suchasni informatsiyni tekhnolohiyi ta innovatsiyni metodyky navchannya $v$ pidhotovtsi fakhivtsiv: metodolohiya, teoriya, dosvid, problemy: zbirnuk naukovykh prats. Vinnytsya. № 41. S. 3-7.

Amhag, L., Hellström, L., Stigmar, M. (2019). Teacher educators' use of digital tools and needs for digital competence in higher education. Journal of Digital Learning in Teacher Education. 35 (4). Pp. 203-220. [in English].

Tymchyna, N. S., Tymchyna, V. I., Pozdnyakova, T. Ye. (2019). Sayt yak skladova informatsiynoho seredovyshcha zakladu osvity [Site as a component of the information environment of an educational institution]. Nova pedahohichna dumka: naukovo-metodychnyy zhurnal. Rivne: ROIPPO. № 2 (98). S. 61-65. [in Ukrainian].
Krutova, N. I. (2019). Intehratsiya informatsiyno-komunikatsiynykh tekhnolohiy u systemu pidvyshchennya kvalifikatsiyi pedahohichnykh pratsivnykiv [Integration of information and communication technologies in the system of teachers' professional skills improvement]. Nova pedahohichna dumka: naukovo-metodychnyy zhurnal. Rivne: ROIPPO. № 1 (97). S. 34-36. [in Ukrainian].

Martin, A. (2020). How to optimize online learning in the age coronavirus (COVID-19): a 5-point for guide for educators. UNSW Newsroom. Vol. 53. № 9. Pp. 1-30. [in English].

Дата надходження до редакиіï: 21.04.2021 p. 